\title{
MODEL DIRECT INSTRUCTION UNTUK MENGEMBANGKAN KEMAMPUAN PENETAPAN ANGKA KREDIT GURU SEBAGAI UPAYA PENINGKATAN KOMPETENSI CALON GURU SEJARAH PROFESIONAL
}

\author{
Ipong Jazimah, Arifin Suryo Nugroho \\ Pendidikan Sejarah FKIP Universitas Muhammadiyah Purwokerto, email: \\ arifinsuryonugroho@gmail.com
}

\begin{abstract}
The problems in this study are 1) How to apply the direct instruction model to develop the ability to determine teacher credit points as an effort to increase the competence of prospective professional history teachers 2) What are the results of improving student abilities that have been achieved by applying the direct instruction model 3) What are the obstacles faced and how to attempt to solve it. This research uses a qualitative approach. Data sources consist of documents and informants. Documents in the form of books, magazines, journals, pretest and posttest results. Data were collected by recording documents, observations, and interviews. The data validity was done by means of data triangulation. Data analysis used interactive analysis with three stages of analysis, namely data reduction, data presentation, and drawing conclusions. This research results in the conclusion that 1) The direct instruction learning model can improve understanding of the material, 2) Studying the material for teacher credit scores makes education study program students more creative and innovative in creating new ideas, 3) The need for educational study program students to be equipped with the ability material for teacher credit scores so that later when they become teachers they become professional teachers with teacher professional rank lines.
\end{abstract}

Keywords: Direct instruction learning model, teacher credit score

\begin{abstract}
ABSTRAK
Permasalahan dalam penelitian ini adalah 1) Bagaimana penerapan model direct instruction untuk mengembangkan kemampuan penetapan angka kredit guru sebagai upaya peningkatan kompetensi calon guru sejarah profesional 2) Bagaimana hasil peningkatan kemampuan mahasiswa yang telah dicapai dengan penerapan model direct instruction 3) Apa saja kendala yang dihadapi dan bagaimana upaya untuk mengatasinya. Penelitian ini menggunakan pendekatan kualitatif. Sumber data terdiri atas dokumen dan informan. Dokumen berupa buku, majalah, jurnal, hasil pretes dan postes. Pengambilan data ditempuh dengan mencatat dokumen, observasi, dan wawancara. Validitas data dilakukan dengan cara trianggulasi data. Analisis data
\end{abstract}


menggunakan analisis interaktif dengan tiga tahapan analisis, yakni reduksi data, penyajian data, dan penarikan simpulan. Penelitian ini menghasilkan kesimpulan bahwa 1) Model pembelajaran direct instruction dapat meningkatkan pemahaman materi, 2) Mempelajari materi angka kredit guru membuat mahasiswa program studi kependidikan menjadi lebih bisa kreatif dan inovatif menciptakan ide-ide baru, 3) Perlunya mahasiswa program studi kependidikan dibekali dengan kemampuan materi angka kredit guru agar nantinya saat menjadi guru mereka menjadi guru yang profesional dengan alur kepangkatan profesional guru.

Kata kunci: Model pembelajaran direct instruction, angka kredit guru

\section{PENDAHULUAN}

Mulai 1 Januari tahun 2013 mulai diberlakukan Peraturan Menteri Negara Pendayagunaan Aparatur Negara dan Reformasi Birokrasi (Permenneg PAN dan RB) Nomor 16 Tahun 2009 tentang jabatan fungsional guru dan angka kreditnya. Perbedaan dengan peraturan sebelumnya adalah diwajibkannya kegiatan Pengembangan Keprofesian Berlanjut (PKB) sebagai salah satu unsur utama dalam Penilaian Kinerja Guru (PKG) untuk kemudian ditetapkan dalam bentuk perolehan angka kredit. Pada peraturan sebelumnya kegiatan Pengembangan Keprofesian Berlanjut (PKB) disebut dengan istilah Pengembangan Profesi dan diwajibkan sebagai syarat kenaikan pangkat/golongan VI/a ke atas. Peraturan yang terbaru ini Pengembangan Keprofesian Berlanjut (PKB) diwajibkan sebagai syarat kenaikan pangkat/golongan mulai dari III/b ke atas dengan minimal jumlah angka kredit yang bervariasi berdasarkan jenjang pangkat/golongannya.

Perubahan peraturan tersebut menimbulkan konsekuensi bahwa semua guru harus melakukan Pengembangan Keprofesian Berlanjut (PKB) sejak dini. Hal ini sesuai dengan peran guru sebagai sebuah profesi setelah seorang guru mendapatkan sertifikat pendidik yang profesional. Kegiatan Pengembangan Keprofesian Berlanjut (PKB) ini dilakukan untuk meningkatkan kualitas guru dari waktu ke waktu sesuai dengan fungsi dan perannya dalam meningkatkan kualitas pembelajaran di sekolah. Peningkatan kualitas pembelajaran di sekolahsekolah diharapkan akan membawa dampak pada meningkatnya kualitas pendidikan di Indonesia.

Seorang guru harus sudah benar-benar memahami tentang sistem Penilaian Kinerja Guru (PKG) secara detail. Unsur yang dipertimbangkan dalam Penilaian Kinerja Guru PKG adalah kompetensi guru itu sendiri. Kompetensi tersebut tidak 
dapat dipisahkan dari kemampuan seorang guru dalam penguasaan pengetahuan, penerapan pengetahuan dan keterampilan sebagaimana diamanatkan dalam Peraturan Menteri Pendidikan Nasional Nomor 16 Tahun 2007 tentang Standar Kualifikasi Akademik dan Kompetensi Guru (Nanang \& Tito, 2013 : 2). Pentingnya penilaian kompetensi guru terutama terkait pertimbangan bahwa penguasaan kompetensi dan penerapan pengetahuan serta ketrampilan guru, sangat menentukan tercapainya kualitas proses pembelajaran dan pembimbingan peserta didik.

Kenyataan di lapangan seringkali berbeda, guru umumnya masih bingung bagaimana cara menghitung angka kredit mereka untuk kenaikan pangkat/golongan. Guru belum tahu indikator apa saja yang dapat membuat angka kredit mereka bisa bertambah dengan cepat. Komponen penilaian untuk penambahan angka kredit meliputi 1) unsur pembelajaran 2) unsur pembimbingan khusus guru konseling 3) tugas tambahan yang relevan seperti kepala sekolah/kepala laboratorium (Nanang \& Tito, 2013: 2). Untuk penilaian pembelajaran meliputi kompetensi pedagogik, profesional, sosial, dan kepribadian. Sehingga untuk penambahan angka kredit tidak hanya mengajar saja tapi juga meliputi kegiatan yang lain seperti membuat penelitian, mengikuti seminar atau workshop dan menghasilkan karya tulis atau benda lain.

Lebih lengkapnya tugas dan tanggung jawab guru dalam rangka mengembangkan profesi adalah guru bertugas sebagai pengajar, pembimbing, administrator kelas, pengembang kurikulum, mengembangkan profesi, dan membina hubungan dengan masyarakat (Tukiran dkk, 2016: 1). Tenaga kependidikan menempati tempat yang sangat sentral dan strategis dalam pembangunan suatu bangsa. Perannya sangat fundamental untuk pembangunan pribadi dan sosial oleh karena itu standar kemampuan profesional profesi pendidikan tidak dapat diundur lagi. Kualitas pendidikan harus meliputi kualitas guru-gurunya juga karena guru adalah pondasi utama pendidikan sehingga tidak boleh goyah.

Peningkatan kualitas guru bisa dimulai sejak para calon guru berada di bangku perkuliahan. Kualitas yang baik tidak bisa didapatkan secara instan namun harus bertahap dan berkelanjutan. Profesi sebagai guru memerlukan keahlian khusus sehingga tidak dapat dilakukan oleh sembarang orang di luar bidang pendidikan. Selain mengajar guru juga harus mampu berkomunikasi secara aktif dengan guru lain untuk meningkatkan kualitas pendidikan terkait hal- 
hal seperti merencanakan pembelajaran, membuat keputusan tentang desain sekolah, kolaborasi tentang pengembangan kurikulum, serta partisipasi dalam proses penilaian (Hamzah Uno, 2012: 18).

Untuk mendukung peningkatan kualitas guru, para calon guru yang sedang menempuh perkuliahan pendidikan dibebani dengan beberapa matakuliah wajib pendidikan. Matakuliah tersebut diantaranya matakuliah Profesi Pendidikan, Evaluasi Pembelajaran, Strategi Pembelajaran, Media Pembelajaran, dan Majanemen pendidikan. Matakuliah Profesi Pendidikan berisi tentang gambaran apa saja tugas dan kewajiban yang akan dilakukan oleh seorang guru termasuk tentang materi terkait peningkatan angka kredit guru untuk syarat kenaikan pangkat atau golongan. Pembekalan kepada mahasiswa di awal ini diharapkan mampu meningkatkan pemahaman dan kemampuan calon guru agar tidak lagi terjadi kebingungan bagaimana caranya menambah dan menghitung angka kredit.

Diperlukan strategi pembelajaran yang tepat untuk mempelajari tentang penghitungan angka kredit guru karena mahasiswa harus praktek secara langsung selain itu mahasiswa dituntut aktif untuk menangkap situasi dan kondisi di sekitarnya agar mudah menemukan ide-ide untuk membuat sebuah penelitian atau karya tulis lain. Strategi yang tepat untuk meningkatkan pemahaman dan kemampuan mahasiswa dalam menghitung angka kredit guru adalah model pembelajaran direct instruction atau pengajaran langsung.

Model pembelajaran direct instruction adalah salah satu pendekatan mengajar yang dirancang khusus untuk menunjang proses belajar siswa yang berkaitan dengan pengetahuan deklaratif dan pengetahuan prosedural yang terstruktur dengan baik yang diajarkan dengan pola kegiatan yang bertahap selangkah demi selangkah (Trianto, 2007: 29). Pengetahuan deklaratif adalah pengetahuan tentang sesuatu yang bisa diungkapkan dengan kata-kata sedangkan pengetahuan prosedural adalah pengetahuan tentang bagaimana melakukan sesuatu. Penggunaan pengetahuan prosedural memerlukan penguasaan pengetahuan prasyarat yang berupa pengetahuan deklaratif. Pengetahuan prosedural dalam model pembelajaran direct instruction inilah yang sangat penting untuk mempelajari penghitungan angka kredit guru.

Langkah-langkah dalam model pembelajaran direct instruction dilakukan secara tertib dan sistematis, cocok dengan kompetensi guru yang dicapai demi menambahkan jumlah angka kredit. Langkah-langkah dalam direct instruction 
adalah 1) menyampaikan tujuan dan menyiapkan siswa 2) menyampaikan tujuan 3) menyiapkan siswa 4) presentasi dan demosnstrasi 5) mencapai kejelasan 6) melakukan demonstrasi 7) mencapai pemahaman dan penguasaan 8) berlatih 9) memberikan latihan terbimbing 10) mengecek pemahaman dan memberikan umpan balik 10) memberikan kesempatan latihan mandiri.

Penelitian ini akan dilakukan di matakuliah Profesi Pendidikan yang ditempuh oleh mahasiswa semester 1 Prodi Pendidikan Sejarah tahun ajaran 2019/2020 waktu pelaksanaan perkuliahan dari September - Januari. 4 bulan pertama waktu penelitian bisa digunakan untuk mengumpulkan data dan 4 bulan berikutnya untuk mengolah data dan membuat laporan penelitian. Pembekalan mengenai angka kredit dilakukan di awal perkuliahan sebagai calon guru dengan tujuan mahasiswa mempunyai pondasi kuat untuk mengetahui dan kemudian memahami apa saja yang harus mereka lakukan untuk menjadi guru yang profesional. Pada saat sudah menjalani profesi sebagai guru tidak ada lagi kebingungan tentang bagaimana cara meningkatkan jumlah angka kredit serta bagaimana cara menghitungnya.

Berdasarkan penelitian-penelitian yang telah dilakukan oleh ilmuwan Stalling dan Kaskowitz menunjukkan bahwa alokasi waktu dan penggunaan tugas (kegiatan) yang menggunakan model pengajaran langsung lebih berhasil dan memperoleh tingkat keterlibatan yang tinggi daripada mereka yang menggunakan metode-metode informal dan berpusat pada siswa (Trianto, 2007: 33). Guru yang memiliki kelas yang terorganisasikan dengan baik dengan menggunakan model pembelajaran direct instruction menghasilkan rasio keterlibatan siswa yang lebih tinggi daripada guru yang menggunakan pendekatan yang kurang formal dan kurang terstruktur. Hal ini menunjukkan bahwa model pembelajaran direct instruction memiliki tingkat keberhasilan yang tinggi jika dilakukan dengan langkah-langkah yang tepat.

\section{METODE PENELITIAN}

Penelitian ini menggunakan metode penelitian kualitatif dan terarah pada sasaran dengan satu karakteristik (lokasi atau satu subyek) yaitu meneliti tentang model pembelajaran direct instruction untuk meningkatkan pemahaman mahasiswa tentang materi angka kredit guru pada mahasiswa Prodi Pendidikan Sejarah FKIP Universitas Muhammadiyah Purwokerto. Objek penelitian adalah 
mahasiswa semester I dengan waktu penelitian selama 8 bulan dari mulai bulan November 2019 sampai Juli 2020.

Sumber data dalam penelitian ini adalah pertama, dokumen untuk mencari data-data tentang pembelajaran direct instruction. Dokumen yang digunakan berupa buku dan jurnal. Kedua, sumber data informan digunakan untuk menggali informasi mengenai bagaimana pelaksanaan model pembelajaran direct instruction. Informan yang dimaksud dalam penelitian ini adalah mahasiswa semester I yang menempuh matakuliah Profesi Pendidikan.

Sesuai dengan bentuk penelitian kualitatif dan jenis sumber data yang dimanfaatkan, maka teknik pengumpulan data yang digunakan dalam penelitian ini adalah pertama, mencatat dokument yang berfungsi untuk mencari data-data tentang pembelajaran direct instruction. Kedua, wawancara yang digunakan dalam penelitian ini adalah wawancara mendalam. Wawancara jenis ini dilakukan tidak dengan cara formal terstruktur untuk menggali pandangan subjek yang diteliti. Subjek yang diteliti posisinya lebih berperan sebagai informan daripada sebagai responden. Peneliti mengambil wawancara model ini karena wawancara mendalam bersifat longgar dan lentur, sehingga dapat menciptakan suasana yang akrab antara peneliti dengan mahasiswa. Ketiga, observasi yang digunakan adalah observasi langsung dengan partisipasi aktif. Peneliti aktif terlibat dalam proses pembelajaran direct instruction dan ikut secara langsung membimbing mahasiswa dalam setiap proses pelatihan, dan umpan balik. Dalam observasi ini, peneliti ikut melakukan apa yang dilakukan nara sumber, tetapi tidak terlibat dalam semua kegiatannya.

Trianggulasi yang digunakan dalam penelitian ini adalah trianggulasi data. Pada trianggulasi data ini dalam pengumpulan data wajib menggunakan beragam sumber data yang berbeda-beda yang tersedia, artinya data yang sejenis akan lebih mantap kebenarannya bila digali dari beberapa sumber data yang berbeda. Sehingga apa yang diperoleh dari sumber yang satu bisa lebih teruji kebenarannya bilamana dibandingkan dengan data sejenis yang diperoleh dari sumber lain yang berbeda, baik kelompok sumber sejenis atau sumber yang berbeda jenisnya. Dalam penelitian ini menggunakan kasus tunggal dengan mengupas permasalahan tentang pembelajaran direct instruction di Prodi Pendidikan Sejarah FKIP UMP. Teknik yang digunakan untuk menganalisis kasus pada penelitian ini menggunakan Miles dan Huberman yang meliputi 
pengumpulan data, reduksi data, penyajian data, simpulan-simpulan, dan penarikan simpulan atau verifikasi (Sugiyono, 2005:91).

\section{HASIL DAN PEMBAHASAN \\ Model Pembelajaran Direct instruction}

Pada penelitian ini, sebelum pelaksanaan model pembelajaran direct instruction dilakukan lebih dulu mahasiswa diberikan pretes. Tujuannya untuk mengetahui sejauh apa pemahaman mahasiswa tentang materi angka kredit guru. Dari pretes yang telah dilakukan, diketahui bahwa kemampuan pengetahuan tentang pengertian angka kredit hanya $30 \%$ mahasiswa saja yang memahaminya. Pengetahuan tentang beban kerja guru hanya diketahui 50\% mahasiswa. Pengetahuan tentang jenjang jabatan fungsional guru hanya diketahui $40 \%$. Pengetahuan tentang fungsi angka kredit guru diketahui hanya $20 \%$ mahasiswa. Pengetahuan tentang manfaat angka kredit guru hanya diketahui $25 \%$ mahasiswa. Cara mendapatkan nilai angka kredit guru hanya diketahui 30\% mahasiswa. Cara menghitung nilai angka kredit guru hanya diketahui 30\% mahasiswa. Cara meningkatkan jumlah angka kredit guru hanya diketahui $25 \%$ mahasiswa.

Tahapan pretes telah dilakukan, peneliti kemudian melangkah ke tahapan selanjunya yaitu pelaksanaan direct instruction. Pada tahap ini peneliti melakukan perkuliahan dengan model pembelajaran direct instruction yang tahapan-tahapannya adalah sebagai berikut:

Tabel 1: Tahapan pelaksanaan model Direct Instruction

\begin{tabular}{|c|l|l|}
\hline Fase & \multicolumn{1}{|c|}{ Kegiatan } & \multicolumn{1}{c|}{ Peran Dosen } \\
\hline Fase 1 & $\begin{array}{l}\text { Menyampaikan tujuan } \\
\text { dan mempersiapkan siswa }\end{array}$ & $\begin{array}{l}\text { Dosen menjelaskan tentang tujuan } \\
\text { pembelajaran yang akan dilakukan, } \\
\text { model pembelajarannya seperti apa dan } \\
\text { tugas-tugas apa saja yang akan } \\
\text { dibebankan kepada mahasiswa }\end{array}$ \\
\hline
\end{tabular}




\begin{tabular}{|l|l|l|}
\hline Fase 2 & $\begin{array}{l}\text { Mendemonstrasikan } \\
\text { pengetahuan dan } \\
\text { keterampilan }\end{array}$ & $\begin{array}{l}\text { Dosen menjelaskan kepada mahasiswa } \\
\text { tentang pengertian angka kredit, } \\
\text { Dosen mendemonstrasikan ketrampilan } \\
\text { dengan benar atau menyajikan } \\
\text { informasi tahap demi tahap }\end{array}$ \\
\hline Fase 3 & Membimbing pelatihan & $\begin{array}{l}\text { Dosen merencanakan dan memberi } \\
\text { bimbingan pelatihan awal pada } \\
\text { mahasiswa }\end{array}$ \\
\hline Fase 4 & $\begin{array}{l}\text { Mengecek pemahaman } \\
\text { dan memberikan umpan } \\
\text { balik }\end{array}$ & $\begin{array}{l}\text { Mengecek apakah mahasiswa telah } \\
\text { berhasil melakukan tugas dengan baik, } \\
\text { memberi umpan balik }\end{array}$ \\
\hline Fase 5 & $\begin{array}{l}\text { Memberikan kesempatan } \\
\text { untuk pelatihan lanjutan }\end{array}$ & $\begin{array}{l}\text { Dosen mempersiapkan kesempatan } \\
\text { melakukan pelatihan lanjutan, dengan } \\
\text { perhatian khusus pada penerapan } \\
\text { kepada situasi lebih kompleks dan } \\
\text { kehidupan sehari-hari }\end{array}$ \\
\hline
\end{tabular}

Pada fase 1 dan fase 2 dosen memberikan ceramah tentang materi angka kredit guru yang meliputi beberapa sub bab materi yaitu tugas pokok dan fungsi guru, beban kerja guru, jenjang jabatan fungsional guru, unsur penilaian angka kredit, dan rincian kegiatan guru dan angka kreditnya. Pada fase ini mahasiswa perlu untuk mengetahui dan memahami mengapa mereka harus mempelajari tentang materi angka kredit guru serta apa fungsi dan manfaatnya setelah materi ini selesai dipelajari. Pada fase persiapan, dosen lebih dulu memotivasi mahasiswa dan menarik perhatiannya agar siap menerima materi perkuliahan serta sedikit mengingatkan kembali tentang materi sebelumnya. Pada fase ini dosen lebih banyak melakukan ceramah yang diselingi dengan tanya jawab untuk mengecek daya tangkap mahasiswa. Dosen juga banyak memberikan contohcontoh kasus tentang penggunaan angka kredit guru di sekolah. Salah satu contoh tentang angka kredit guru yang disampaikan oleh dosen dalam pembelajaran model direct instruction ini yang diambil dari buku karangan Nana Priatna dan Tito Sukamto yang berjudul Pengembangan Profesi Guru adalah sebagai berikut: 
Seorang guru bernama Pak Danu mendapatkan nilai hasil PKG kategori CUKUP yang di angka kreditkan sebesar 14,25. Jika Pak Danu secara konsisten selama 4 tahun hanya memperoleh predikat CUKUP maka nilai angka kredit yang didapatkannya adalah $4 \times 14,25=57$. Karena persyaratan untuk naik jenjang ke golongan III/d adalah 100, maka Pak Danu tidak akan bisa naik pangkat. Satu-satunya cara agar naik pangkat adalah Pak Danu harus menambah nilai angka kredit sebesar 43. Penambahan angka kredit ini bisa didapat dari sub unsur publikasi ilmiah, karya inovatif, sub unsur pengembangan diri atau dari tugas tambahan.

Dengan memberikan contoh tersebut dosen ingin menyampaikan kepada mahasiswa, apabila sudah berprofesi sebagai guru maka tidak cukup hanya mengandalkan nilai angka kredit dari PKG (Penilaian Kinerja Guru) saja melainkan guru harus kreatif mencari nilai angka kredit dari sub unsur lain seperti pengembangan, karya ilmiah, dan karya inovatif yang lainnya.

Fase selanjutnya yaitu fase 3 adalah membimbing pelatihan yang terdiri dari kegiatan menugasi mahasiswa melakukan latihan singkat dan bermakna. Melanjutkan dari fase sebelumnya bahwa mahasiswa harus dimulai dari sekarang berlatih kreatif memunculkan ide-ide baru untuk mendapatkan nilai angka kredit selain dari PKG. Latihan dalam pembelajaran model direct instruction kali ini adalah latihan membuat karya ilmiah atau karya inovatif yang bernilai angka kredit tinggi. Mahasiswa diminta untuk mencari ide sebuah karya ilmiah yang bisa ditulis atau karya inovatif yang bisa dibuat. Latihan ini berfungsi untuk melatih mahasiswa agar nantinya ketika mereka sudah menjadi guru terbiasa untuk membuat karya ilmiah dan karya inovatif.

Dari latihan ini salah satu contohnya seperti yang dilakukan mahasiswa bernama Rani Mustafa yang mempunyai ide tentang karya ilmiah "Saya mempunyai ide membuat buku tentang sejarah kerajaan Hindu-Budha dan Islam. Buku yang saya buat memiliki banyak aspek penting untuk dipelajari. Di dalam buku tersebut terdapat sejarah-sejarah kerajaan yang ada di Indonesia dan peranan pentingnya. Cara membuat buku tersebut saya menyusunnya dengan mengumpulkan data-data (materi pokok) untuk dirumuskan menjadi satu dalam media cetak. Manfaat dari buku tersebut agar menjadi lebih tahu bagaimana perkembangan-perkembangan kerajaan yang berperan penting pada masanya. Sehingga kita menjadi tahu tentang apa yang terjadi dalam peristiwa pentingnya." 


\section{Kemampuan Mahasiswa tentang Angka Kredit Guru}

Fase pelatihan dan bimbingan mendapatkan hasil yang cukup memuaskan, dibuktikan dengan munculnya ide-ide kreatif mahasiswa tentang tema-tema dalam membuat karya ilmiah atau karya inovatif terkait untuk peningkatan angka kredit guru. Berikut ini hasil-hasil pemikiran mahasiswa tentang ide-ide mereka mengenai karya ilmiah dan karya inovatif yang bisa dilakukan:

Tabel 2: Hasil latihan mahasiswa membuat ide karya ilmiah atau karya inovatif

\begin{tabular}{|l|l|l|}
\hline No. & \multicolumn{1}{|c|}{$\begin{array}{c}\text { Nama } \\
\text { mahasiswa }\end{array}$} & \multicolumn{1}{c|}{ Ide karya ilmiah atau karya inovatif } \\
\hline 1. & $\begin{array}{l}\text { Noorizka } \\
\text { Pradmasahara }\end{array}$ & $\begin{array}{l}\text { Buku pegangan untuk siswa yang saya susun sendiri } \\
\text { isinya. Buku pegangan tersebut berisi materi yang akan } \\
\text { saya ajarkan dalam 2 semester. Manfaat jika membuat } \\
\text { buku sendiri adalah materi bisa disesuaikan dengan } \\
\text { yang diajarkan di kelas selain itu juga bisa menambah } \\
\text { angka kredit. }\end{array}$ \\
\hline 2. & $\begin{array}{l}\text { Wulan } \\
\text { Rahmawati }\end{array}$ & $\begin{array}{l}\text { Ide saya adalah membuat blogspot yang berisi artikel- } \\
\text { artikel yang sudah lebih dulu saya masukkan ke jurnal- } \\
\text { jurnal. Tujuan saya adalah selain menambah materi } \\
\text { untuk mahasiswa juga untuk menyimpan secara online } \\
\text { artikel-artikel saya yang sudah masuk jurnal. }\end{array}$ \\
\hline 3. & $\begin{array}{l}\text { Ar Lathif } \\
\text { Syamjaya }\end{array}$ & $\begin{array}{l}\text { Membuat film animasi karena anak jaman sekarang } \\
\text { lebih senang melihat film dari pada baca buku. Supaya } \\
\text { film lebih menarik maka dibuat animasi supaya tidak } \\
\text { bosan saat menonton. Manfaatnya adalah supaya } \\
\text { generasi muda itu tidak akan melupakan sejarah }\end{array}$ \\
\hline 4. & Meida Nia W & $\begin{array}{l}\text { Saya ingin menciptakan aplikasi belajar tanpa harus } \\
\text { membawa buku yaitu aplikasi bernama "ruang sejarah" } \\
\text { yang terdiri dari 3 menu pilihan yaitu sejarah lokal (dari } \\
\text { wilayah masing-masing), sejarah nasional (seluruh } \\
\text { Indonesia), sejarah internasional (seluruh dunia). } \\
\text { manfaat dari adanya ruang sejarah ini, siswa bisa }\end{array}$ \\
\hline
\end{tabular}




\begin{tabular}{|l|l|l|}
\hline & & $\begin{array}{l}\text { belajar sejarah dalam 3 kategori sekaligus saya bisa } \\
\text { mendapatkan nilai untuk angka kredit dari pembuatan } \\
\text { aplikasi ini. }\end{array}$ \\
\hline 5 & $\begin{array}{l}\text { Dwi Utari } \\
\text { Anggraeni }\end{array}$ & $\begin{array}{l}\text { Pembuatan vlog mengenai materi sejarah berupa } \\
\text { peninggalan bersejarah. Dengan cara membuat video } \\
\text { tentang materi tersebut, misalnya jika peninggalan } \\
\text { terjangkau maka langsung didatangi. Contoh } \\
\text { peninggalan sejarah candi borobudur, maka video } \\
\text { berisi tentang sejarah berdirinya, proses pembuatan } \\
\text { bangunannya, bangunan apa saja yang ada di sekitarnya } \\
\text { dan proses penetapan candi borobudur sebagai cagar } \\
\text { budaya Unesco. Manfaatnya adalah adanya gaya baru } \\
\text { dalam pembelajaran dan bisa menjadi contoh bagi guru } \\
\text { lain. Jika sudah dipublish di laman berbagi seperti } \\
\text { youtube artinya sudah memanfaatkan IT dan bisa } \\
\text { menambah angka kredit guru sebagai sebuah karya } \\
\text { inovatif. }\end{array}$ \\
\hline 6. & Indri Aprianti \\
\hline $\begin{array}{l}\text { Membuat alat peraga dari kardus (peninggalan pra } \\
\text { aksara) dengan cara memotong kardus menjadi bentuk } \\
\text { yang kita inginkan dan ditempelkan menggunakan lem. } \\
\text { Manfaatnya agar siswa lebih memahami dan } \\
\text { mengetahui bentuk dari peninggalan pra aksara } \\
\text { sehingga tidak hanya melihat gambar dan } \\
\text { membayangkan. }\end{array}$ \\
\hline $\begin{array}{l}\text { Membuat e-book berupa ringkasan materi pelajaran } \\
\text { dengan cara meringkas materi-materi yang akan } \\
\text { diajarkan kemudian diketik dalam bentuk pdf atau word } \\
\text { kemudian dibagikan kepada siswa dan bisa untuk } \\
\text { menjadi selingan pelajaran. Dalam e-book tersebut bisa } \\
\text { ditambahkan dengan gambar-gambar berwarna atau } \\
\text { animasi sehingga siswa tidak jenuh dengan materi yang } \\
\text { ada. Kelebihannya adalah praktis karena bisa disimpan } \\
\text { di dalam HP. }\end{array}$ \\
\hline
\end{tabular}




\begin{tabular}{|l|l|l|}
\hline 8. & $\begin{array}{l}\text { Tri Ajeng } \\
\text { Wulandari }\end{array}$ & $\begin{array}{l}\text { Membuat komik sejarah. Kita tahu bahwa anak-anak itu } \\
\text { banyak yang tidak suka membaca, sehingga jika dibikin } \\
\text { dalam bentuk komik akan lebih menarik. Dalam } \\
\text { pembuatan komiknya pun harus sesuai dengan sejarah } \\
\text { yang ada, dengan gambar yang dibuat semenarik } \\
\text { mungkin. }\end{array}$ \\
\hline 9. & $\begin{array}{l}\text { Fajar Eko } \\
\text { Wahyudi }\end{array}$ & $\begin{array}{l}\text { Membuat contoh peralatan yang digunakan pada masa } \\
\text { pra aksara dengan menggunakan kardus bekas atau } \\
\text { stereofom. Bahan pembuatan dilapisi kertas warna agar } \\
\text { lebih menarik atau bisa juga dicat air. Dengan adanya } \\
\text { contoh tersebut maka siswa dapat mengetahui dengan } \\
\text { jelas bentuk dan juga fungsi dari alat-alat tersebut. }\end{array}$ \\
\hline 10. & $\begin{array}{l}\text { Reni Kanti } \\
\text { Widiastuti }\end{array}$ & $\begin{array}{l}\text { Membuat blog di website terkait materi sejarah. } \\
\text { Membuat bacaan tentang sejarah dengan } \\
\text { mencantumkan gambar-gambar animasi sejarah agar } \\
\text { siswa tidak mengantuk. Blog-blog materi pendidikan } \\
\text { sejarah dibuat semenarik mungkin agar siswa atau } \\
\text { murid tidak mengantuk saat membacanya. }\end{array}$ \\
\hline 11. & $\begin{array}{l}\text { Alika } \\
\text { Rihadatul A. }\end{array}$ & $\begin{array}{l}\text { Membuat video pembelajaran atau vlog edukasi dengan } \\
\text { cara kita mengambil sebuah foto suatu situs yang diberi } \\
\text { keterangan atau foto yang menarik agar menjadi sebuah } \\
\text { karya inovatif yang bisa digunakan sebagai } \\
\text { pembelajaran. Vlog yang dibuat ketika mengunjungi } \\
\text { sebuah situs tetapi dalam penjelasannya diusahakan } \\
\text { semenarik mungkin agar siswa yang melihat tidak } \\
\text { mudah bosan. }\end{array}$ \\
\hline $\begin{array}{l}\text { Saya akan membuat animasi dimana suaranya diisi oleh } \\
\text { suara saya sendiri. Animasi tentang kejadian sejarah } \\
\text { dan siapa sajakah tokoh-tokoh sejarah yang ada pada } \\
\text { saat itu. Selain itu bisa juga dengan membuat miniatur } \\
\text { busa/gabus yang mudah dibentuk dan ditempelkan } \\
\text { gambar print di bagian depan gabus/busa tersebut. }\end{array}$ \\
\hline
\end{tabular}




\begin{tabular}{|c|c|c|}
\hline & & $\begin{array}{l}\text { Manfaatnya adalah supaya siswa memhami lebih dalam } \\
\text { lagi tentang materi yang disampaikan oleh guru. }\end{array}$ \\
\hline 13. & $\begin{array}{l}\text { Faqih Al } \\
\text { Fauzan }\end{array}$ & $\begin{array}{l}\text { Saya akan membuat chanel youtube yang berisi } \\
\text { pembelajaran tentang materi yang berkaitan dengan } \\
\text { sejarah. Video tersebut dibuat dengan cara merekam } \\
\text { penjelasan saya tentang suatu materi dan dibuatkan } \\
\text { gambar ilustrasi seperti video tentang peristiwa sejarah } \\
\text { dan diedit kemudian ditambahkan penjelasan. }\end{array}$ \\
\hline 14. & $\begin{array}{l}\text { Nanda Rizki } \\
\text { Ayu }\end{array}$ & $\begin{array}{l}\text { Membuat vlog ke tempat situs bersejarah Indonesia. } \\
\text { Cara pembuatannya yaitu mendatangi ke tempat situs } \\
\text { bersejarah dengan menyelipkan materi, caranya dengan } \\
\text { membuat vlog bertema liburan seperti jalan-jalan ke } \\
\text { tempat bersejarah seperti monas, kota tua, candi } \\
\text { borobudur, dan lain-lainnya. }\end{array}$ \\
\hline 15. & $\begin{array}{l}\text { Novita Diah } \\
\text { Ayu }\end{array}$ & $\begin{array}{l}\text { Membuat sebuah novel sejarah dengan seting dan tokoh } \\
\text { yang ada di dalamnya sesuai dengan fakta-fakta sejarah } \\
\text { yang ada. }\end{array}$ \\
\hline 16. & $\begin{array}{l}\text { Agung Nova } \\
\text { Rianto }\end{array}$ & $\begin{array}{l}\text { Membuat aplikasi khusus tentang pembelajaran sejarah } \\
\text { yang bernama "momentum sejarah" }\end{array}$ \\
\hline 17. & Aisah & $\begin{array}{l}\text { Membuat boneka mendongeng sejarah. Saya } \\
\text { menyiapkan sebuah boneka yang dibuat didalam } \\
\text { boneka tersebut untuk menyimpan rekaman sebuah } \\
\text { cerita sejarah. Sehingga seolah-olah boneka tersebut } \\
\text { sedang menceritakan sebuah peristiwa sejarah. } \\
\text { Manfaatnya adalah supaya siswa tidak bosan dan ada } \\
\text { inovasi baru dalam penggunaan media pembelajaran. }\end{array}$ \\
\hline 18. & $\begin{array}{l}\text { Amara } \\
\text { Wanda Iriani }\end{array}$ & $\begin{array}{l}\text { Membuat miniatur bangunan dari barang bekas } \\
\text { contohnya adalah miniatur masjid kuno Demak. Dibuat } \\
\text { dari kayu-kayu bekas potongan tukang pembuat mebel. }\end{array}$ \\
\hline 19. & M. Galih P. & $\begin{array}{l}\text { Merancang sebuah laboratorium pembelajaran sejarah. } \\
\text { Sebuah ruangan disetting dengan gambar-gambar }\end{array}$ \\
\hline
\end{tabular}




\begin{tabular}{|l|l|l|}
\hline & & $\begin{array}{l}\text { sejarah, foto-foto sejarah, miniatur-miniatur benda } \\
\text { bersejarah. Laboratotium tersebut bermanfaat sebagai } \\
\text { penunjang pembelajaran siswa tentang materi-materi } \\
\text { sejarah agar lebih variatif dan inovatif }\end{array}$ \\
\hline 20. & $\begin{array}{l}\text { Endy Heru } \\
\text { Wicaksono }\end{array}$ & $\begin{array}{l}\text { Membuat buku penunjang belajar sejarah yang } \\
\text { bertemakan sejarah lokal }\end{array}$ \\
\hline 21. & $\begin{array}{l}\text { Lutfi Bayu } \\
\text { Susanto }\end{array}$ & $\begin{array}{l}\text { Menulis artikel di koran atau surat kabar lokal dengan } \\
\text { tema-tema sejarah atau pendidikan sejarah contohnya } \\
\text { "mengenal museum BRI sebagai sumber belajar } \\
\text { sejarah" }\end{array}$ \\
\hline
\end{tabular}

Pada fase 4 yaitu mengecek pemahaman dan memberikan umpan balik atau bisa juga disebut sebagai tahap resitasi yaitu dosen memberikan pertanyaan lisan atau tertulis kepada mahasiswa kemudian dosen memberikan respon terhadap jawaban mahasiswa. Fase selanjutnya yaitu fase 5 sekaligus fase yang terakhir adalah memberikan kesempatan untuk pelatihan lanjutan dan penerapan. Pada tahap ini dosen memberikan tugas kepada mahasiswa untuk dikerjakan di rumah atau di luar jam perkuliahan untuk membuat contoh-contoh dan menciptakan ide-ide lain yang terkait dengan peningkatan angka kredit yang termaktub dalam PKB (Pengembangan Keprofesian Berkelanjutan) yang jenisjenisnya terbagi dalam 3 yaitu pengembangan diri meliputi kegiatan diklat fungsional dan melaksanakan kegiatan kolektif guru, publikasi ilmiah, dan karya inovatif.

\section{Peningkatan Pemahaman Mahasiswa tentang Angka Kredit Guru}

Setelah selesai pelaksanaan pembelajaran dengan model direct instruction, mahasiswa akan melewati tahapan postes untuk mengetahui sejauh mana peningkatan kemampuan yang berhasil dicapai. Dari postes yang telah dilakukan, diketahui bahwa kemampuan pengetahuan tentang pengertian angka kredit meningkat menjadi $80 \%$ mahasiswa yang memahaminya. Pengetahuan tentang beban kerja guru menjadi $70 \%$ mahasiswa. Pengetahuan tentang jenjang jabatan fungsional guru menjadi $70 \%$. Pengetahuan tentang fungsi angka kredit guru meningkat menjadi $75 \%$ mahasiswa. Pengetahuan tentang manfaat angka kredit guru menjadi 75\% mahasiswa. Cara mendapatkan nilai angka kredit guru meningkat menjadi $80 \%$ mahasiswa. Cara menghitung nilai angka kredit guru 
menjadi 70\% mahasiswa. Cara meningkatkan jumlah angka kredit guru menjadi $85 \%$ mahasiswa.

Penjelasan tersebut menunjukkan bahwa mahasiswa telah mengalami peningkatan sebelum dan sesudah pembelajaran menggunakan model direct instruction. Berikut ini akan dijabarkan beberapa hasil dari pengamatan dan wawancara yang dilakukan oleh dosen untuk menggenapi data-data yang telah didapatkan sebelumnya. Dari hasil tersebut ditemukan fakta bahwa mahasiswa setelah melakukan pelatihan menjadi paham apa itu angka kredit, apa fungsinya dan bagaimana cara meningkatkan jumlah angka kredi guru. Dari mahasiswa yang bernama Tri Ajeng Wulandari "Angka kredit itu penting sekali karena untuk kenaikan pangkat guru dan kenaikan gaji guru. Seorang guru harus melakukan sesuatu untuk mendapatkan angka kredit yang tinggi seperti membuat karya inovatif, karya ilmiah, dan menjadi pembicara di seminar-seminar."

Mahasiswa bernama Tyas Rismawati “ angka kredit guru sangatlah penting karna digunakan sebagai acuan untuk mendapat kenaikan jabatan atau pangkat seorang guru. Cara untuk memperoleh angka kredit guru bisa dari kegiatan Penilaian Kinerja Guru dan kegiatan Pengembangan Keprofesian Berkelanjutan." Dari mahasiswa atas nama Ar Lathif Syamjaya "angka kredit bagi seorang guru sangat penting karena itu adalah syarat untuk kenaikan pangkat dan cara mendapatkannya adalah dengan cara aktif mengajar, mengikuti seminar baik menjadi peserta atau bahkan pembicara, mempublikasikan karya ilmiah."

Mahasiswa bernama Indri Aprianti "angka kredit guru itu sangat penting untuk kenaikan pangkat. Cara untuk memperoleh angka kredit guru dengan cara mengikuti seminar, menjadi pembicara, membuat artikel, membuat buku, membuat karya tulis dan dipublikasikan. Hal itu dilakukan hingga mencapai poin yang diinginkan." Mahasiswa bernama Meida Nia "Angka kredit bagi guru sangat penting karena untuk menunjang jabatan (kenaikan pangkat) guru tersebut dan kenaikan gaji dari guru tersebut. Cara memperoleh angka kredit guru dengan cara menjadi peserta dalam seminar, menjadi pembicara dalam seminar, menciptakan buku guna untuk menunjang pembelajaran di dalam kelas, maka dengan adanya cara tersebut seorang guru bisa menaikkan pangkat secara signifikan.

Dari keterangan mahasiswa-mahasiswa tersebut menjadi bukti bahwa angka kredit guru sangatlah penting sebagai bentuk meningkatkan profesionalitas seorang guru. Sebaiknya pengetahuan tentang angka kredit guru diberikan sejak 
masih dalam status mahasiswa kependidikan agar nantinya ketika mereka sudah menjadi guru telah memiliki bekal pengetahuan yang cukup tentang angka kredit guru. Selain bekal pengetahuan, mahasiswa juga diberikan bekal pelatihanpelatihan tentang bagaimana caranya meningkatkan jumlah angka kredit itu.

\section{SIMPULAN}

Kesimpulan penelitian ini bahwa model pembelajaran direct instruction bisa dijadikan sebagai salah satu model pembelajaran bidang sejarah khususnya mata kuliah Profesi Pendidikan pada materi angka kredit guru karena dipandang bisa meningkatkan pemahaman materi dengan tahapan-tahapan pembelajarannya yang berisi pelatihan-pelatihan, bimbingan, dan umpan balik. Mempelajari materi angka kredit guru membuat mahasiswa program studi kependidikkan menjadi lebih bisa kreatif dan inovatif menciptakan ide-ide baru terkait karya ilmiah dan karya inovatif lain dalam usaha meningkatkan angka kredit guru. Perlunya mahasiswa program studi kependidikkan dibekali dengan kemampuan materi angka kredit guru agar nantinya saat menjadi guru mereka menjadi guru yang profesional dengan alur kepangkatan profesional guru yang terus meningkat dari hari ke hari. Ada beberapa kelebihan dan kekurangan dalam penggunaan model pembelajaran direct instruction ini. Kelebihannya mahasiswa lebih cepat paham dan bisa praktek secara langsung terkait materi yang diajarkan. Kekurangannya adalah model pembelajaran ini membutuhkan banyak waktu karena proses pelatihan, bimbingan, dan umpan balik harus berurutan dan tidak bisa dilakukan secara singkat.

\section{DAFTAR PUSTAKA}

Priatna, Nanang \& Sukamto, Tito. 2013. Pengembangan Profesi Guru. Bandung: PT. Remaja Rosdakarya.

Sugiyono. 2005. Memahami Penelitian Kualitatif. Bandung: Alfabeta.

Sukmadinata, Nana Syaodih. 2006. Metode Penelitian Pendidikan. Bandung: Remaja Rosdakarya.

Supriyadi. 2011. Strategi Belajar dan Mengajar. Yogyakarta: Cakrawala Ilmu. Sutopo. 2006. Metodologi Penelitian Kualitatif: Dasar Teori dan Terapannya dalam Penelitian. Surakarta: Sebelas Maret University Press 
Taniredja, Tukiran dkk. 2016. Guru yang Profesional. Bandung: Alfabeta.

Trianto. 2007. Model-Model Pembelajaran Inovatif Berorientasi Konstruktivistik: Konsep, Landasan Teoritis - Praktis dan Implementasinya. Jakarta: Prestasi Pustaka.

Uno, Hamzah. 2010. Model Pembelajaran: Menciptakan Proses Belajar Mengajar yang Kreatif dan Efektif. Jakarta: Bumi Aksara.

Uno, Hamzah. 2012. Profesi Kependidikan: Problema, Solusi, dan Reformasi Pendidikan di Indonesia. Jakarta: Bumi Aksara. 